Article

\title{
Livelihood Strategies of Rural Households in Ning'er Earthquake-Stricken Areas, Yunnan Province, China
}

\author{
Benyong Wei ${ }^{1, * \mathbb{D}}$, Guiwu Su ${ }^{1}$, Yingkui $\mathrm{Li}^{2}{ }^{2}$ and Yuling $\mathrm{Ma}^{3}$ \\ 1 Institute of Geology, China Earthquake Administration, Beijing 100029, China; suguiwu@ies.ac.cn \\ 2 Department of Geography, University of Tennessee, Knoxville, TN 37996, USA; yli32@utk.edu \\ 3 National Disaster Reduction Center, Ministry of Emergency Management Department, Beijing 100124, China; \\ mayuling@ndrcc.org.cn \\ * Correspondence: bywei1982@ies.ac.cn
}

Received: 20 August 2019; Accepted: 21 October 2019; Published: 24 October 2019

\begin{abstract}
Natural hazards not only cause direct losses of household income and assets but also affect the choice and outcome of livelihood strategies. Based on the questionnaire survey from 2007 on Mw 6.1 Ning'er earthquake-hit areas in Southwest China, we analyzed the relationship between livelihood assets (or capitals) and livelihood strategies of local rural households and identified the main factors influencing the choice of livelihood strategy. The results indicate that statistically significant differences exist in livelihood assets among livelihood strategies. The choice of livelihood strategies is affected significantly by the status of livelihood assets. High financial capitals enable households to engage in higher-returns or capital-intensive livelihood activities. Improving vocational education and skills training for rural residents, especially for the youth, is also important in developing new livelihood strategies beyond their traditional lifestyle. Higher social capitals provide households the opportunity to select a higher return and income livelihood strategy. In addition, as part of efforts to enhance physical capitals, housing construction planning and technical guidance are of critical importance to improve the anti-seismic performance of rural buildings and decrease their livelihood risk in earthquake-prone areas. It is important for farmers to improve and diversify their livelihood strategies according to regional geographical environment and the comparative advantages of their own livelihood assets.
\end{abstract}

Keywords: livelihood capital; livelihood strategy; earthquake; rural household; Yunnan

\section{Introduction}

The human and economic losses induced by natural disasters has increased considerably over the past decades. In addition to losses in household income and livelihood assets, natural disasters may also influence the choices and outcomes of livelihood strategies [1]. The frequently occurred disasters affect risk perceptions and preferences of local households, limiting or changing their future livelihood choices [2,3]. For example, residents may be more inclined to low-risk, low-return activities to avoid losses in a high-risk environment [4,5], but might also hinder livelihood recovery [6]. Developing livelihood adaptation strategies to high-risk environment is beneficial for enhancing livelihood diversity and resilience, maintaining household's livelihood security and improving livelihood recovery after disasters.

The capability of households to choose different livelihood strategies is affected by the characteristics of their livelihood assets or capitals. The adaptation strategies based on livelihood assets are beneficial for maintaining diverse livelihood choices and improving livelihood resilience $[7,8]$. Although many studies have pointed out that it is important to understand the relationships between 
livelihood assets, natural disasters and livelihood strategies [8-10], the work on quantitatively studying their internal connections is still very scarce $[11,12]$.

China is a country affected by some of the most serious natural disasters in the world. The frequent occurrence of natural disasters has a serious impact on local social economy, which is also a main factor leading to the poverty in rural areas. Compared with urban households, rural households are more vulnerable to disasters and more prone to hard daily life after a disaster. In natural disaster-prone areas, disasters could impact the accumulation of livelihood asset, limiting the capability of rural households to recover from the disasters. Rural households usually spend their limited resources for basic lifestyle need after a disaster, hindering their ability to regain agriculture and animal husbandry activities. As a result, their poverty is further intensified by increasing livelihood vulnerability $[13,14]$. Most studies have been conducted to evaluate rural household livelihood in China. Li et al. [15] analyzed rural households' vulnerability by developing a livelihood asset assessment system for 4 areas in China. Yan et al. [16] established a livelihood vulnerability assessment method based on the sustainable livelihood framework in Tibetan Plateau area. He et al. [17] analyzed the spatial distribution of famers' livelihood asset using clustering analysis in Southwest China. Liu et al. [18] applied a sustainable livelihood framework to analyze farmer households' livelihood in the typical mountainous regions of Western China. Hu et al. [19] estimated the effects of an industrial anti-poverty strategy on the rural livelihoods using a Probit model in Shaanxi Province. Quan and Chen [20] assessed the factors influencing the livelihood assets of rural households by employing a Logit model in Hubei Province. Some studies analyzed the relationships between livelihood assets and strategies of rural households in China. For example, Su et al. [21] conducted a preliminary study of the connection between livelihood assets and strategies in Zhangye City, China. He et al. [22] analyzed the relationship between peasants' livelihood asset and tourism livelihood strategy in an area of Northwest China. Liu et al. [23] applied the binary logistic model and multi-logistic model to analyze the influence factors of farmers' household strategies choice and the dynamic of livelihood transition. The general conclusion of these studies showed relatively high livelihood vulnerability of rural area and the choice and transformation of livelihood strategies are determined by livelihood asset endowments.

Although natural disasters and their associated asset losses has a serious harm to rural livelihoods, few studies have been investigated the impacts of natural disaster on rural household livelihood and the adjustment of livelihood strategies after a specific disaster in China. Luo et al. [24] used a livelihood analysis method to investigate rural households' vulnerability to disaster in Jianghan Plain, China. Taking 2008 Wenchuan earthquake-hit area as an example, Han et al. [25] analyzed the livelihood recovery of local rural households in China. The results showed that livelihoods capitals have an increasing trend in all five dimensions, including human, physical, natural, financial and social capitals, after recovering from the earthquake. Wei et al. [26] estimated the livelihood risk of rural households based on a sustainable livelihood framework in Ning'er earthquake-hit areas, Yunnan Province. The results showed that the vulnerable livelihoods of local households had low capacity to deal with the effects of the earthquake. Recently, Qiu et al. [27] analyzed the impacts of a blizzard on rural livelihoods on the Tibetan-Qinghai Plateau and found a negative effect of the disaster on the livelihood assets, which seriously hindered the improvement of residents' livelihood.

An earthquake can destroy a household's livelihood system, reduce the income and intensify the poverty in earthquake-affected areas. It is important for rural residents to adjust their livelihood strategies and enhance their capability to survive and mitigate the negative effects of earthquakes. Since 2007, our team has conducted a series of investigations and studies on disaster perception, response and post-disaster recovery in earthquake-affected areas [3,28-33]. These studies improved our understanding of the processes related to disaster response and post-disaster recovery, providing useful guidance for local earthquake disaster prevention and mitigation. However, most previous studies focused on the public response and household livelihood vulnerability in the earthquake-prone areas. Few studies have focused on the choice of livelihood strategies and their relationships with livelihood assets of rural households in earthquake-stricken areas. The choice of livelihood strategy 
not only determines the current livelihood outcomes of households but also affects the sustainability of their future livelihood. In this paper, taking $2007 \mathrm{Mw}$ 6.1Ning'er earthquake-hit areas as an example, we analyzed the differences of livelihood capitals among various livelihood strategies, quantified the relationship between livelihood capitals and strategies and identified the main factors affecting the choice of livelihood strategy. This study would provide useful insight into the choice of livelihood strategy in the earthquake-affected area.

\section{Data and Method}

\subsection{Research Area}

This study focuses on Ning'er County, southern Yunnan Province, China, which was the main area struck by the $M w 6.1$ earthquake in 2007. This earthquake damaged many buildings; killed 3 , injured more than 300 and affected 536,000 populations [34]. The disaster area reached up to $3890 \mathrm{~km}^{2}$. The number of households affected by this earthquake was up to 31,919 , accounting for $60.5 \%$ of the households in Ning'er County (Figure 1).

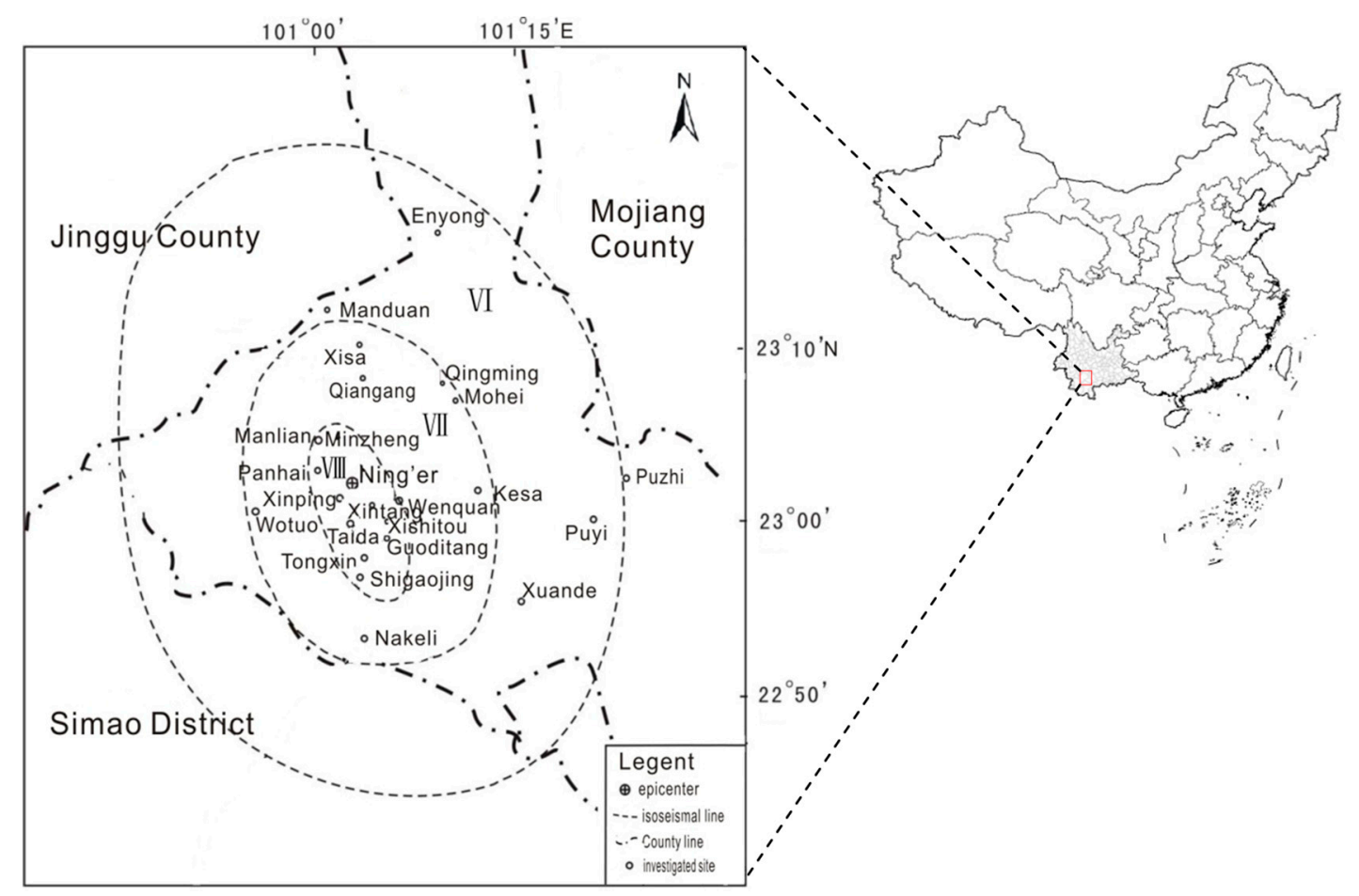

Figure 1. Study area and the surveyed spots.

The total area of the Ning'er County is $3670 \mathrm{~km}^{2}$, including six towns and three townships. The total population is 195 thousand with $55.5 \%$ minorities. In 2015, the GDP of the county was 4.27 billion RMB. The disposable income per capita was $23,852 \mathrm{RMB}$ and $8125 \mathrm{RMB}$ for urban and rural residents, respectively.

Ning'er County is located in an earthquake-prone area due to its complex geological structure and faults. Table 1 lists 6 historic earthquakes with Ms 6.0 and above happened in this area. The frequently occurred earthquakes have caused enormous human and economic losses in this area.

\subsection{Sustainable Livelihood Approach}

The choice of livelihood strategy is directly affected by households' livelihood assets endowment, determining future economic development and well-being. To achieve the sustainable livelihood development, it is necessary to understand the status of households' livelihood assets and the interaction 
between family livelihood assets and external environment. The asset-based Sustainable Livelihood Approach (SLA) is a suitable tool for understanding rural livelihood and identifying driving factors of sustainable rural development and poverty reduction [35]. The SLA considers both tangible (including resources and stores) and intangible assets (such as claims and access), which are crucial to build a livelihood [36]. The SLA has proven useful for assessing the capability of households to deal with external shocks, such as natural disasters, climate change and disease [9-12,35]. It has also been used as a prominent tool in many developmental programs to reduce poverty and livelihood vulnerability in rural households $[37,38]$.

Table 1. Historic earthquakes ( $\geq$ Ms 6.0) in Ning'er County.

\begin{tabular}{ccccccc}
\hline Time & Magnitude & Epicenter & $\begin{array}{c}\text { Epicentral } \\
\text { Intensity }\end{array}$ & Death & Injury & $\begin{array}{c}\text { Economic Loss/ } \\
\text { Thousand RMB }\end{array}$ \\
\hline Feb. 07,1970 & 6.2 & Dehua & VII & 0 & 0 & - \\
Apr. 28,1971 & 6.7 & Tongxin & X & 2 & 86 & - \\
Aug. 16,1973 & 6.5 & Tongxin & VIII & 0 & 72 & - \\
Mar. 15,1979 & 6.8 & Mohei & IX & 12 & 563 & 16,338 \\
Sep. 19,1981 & 6.0 & Puyi & VII & 2 & 21 & 3670 \\
Jan. 27,1993 & 6.3 & Tongxin & VIII & 0 & 154 & $2,557,532$ \\
\hline \multicolumn{7}{c}{ "_" indicates no data. }
\end{tabular}

\subsection{Livelihood Capital Indicators for Rural Households}

Livelihood capital (or asset), including both material and social resources relative to household livelihood, is the core of the livelihood analysis [39]. The sustainable livelihood framework divides livelihood capitals into five categories, including human capital (such as skills, knowledge, health), physical capital (e.g., basic infrastructure and household devices), natural capital (natural resource, including farmland, water, crops and so on), financial capital (such as deposit, income, bonds) and social capital (social resources and network, including degree of trust, reliability and others). These five livelihood assets are the key elements of SLA (The details could be found in the papers from Chambers \& Conway [36] and DFID [39]). Based on the classification and preliminary research, we establish the main indicators of livelihood capitals for rural households in Ning'er earthquake-hit area (Table 2).

Table 2. Estimation indicators of rural livelihood capitals in the studied area.

\begin{tabular}{lll}
\hline \multicolumn{1}{c}{ Component } & \multicolumn{1}{c}{ Weight } & \multicolumn{1}{c}{ Indicators } \\
\hline Human capital & 0.24 & $\begin{array}{l}\text { percentage of male (0.33), percentage of healthy adults }(0.33,18-60 \text { old } \\
\text { years) and percentage of highly educated people }(0.33)\end{array}$ \\
\hline Physical capital & 0.18 & the building structure \\
\hline Natural capital & 0.25 & crop area per capita \\
\hline Financial capital & 0.16 & household savings (0.50); annual family income (0.50) \\
\hline Social capital & 0.17 & $\begin{array}{l}\text { the ways of funds and material sources to restore and rebuild for } \\
\text { families }\end{array}$ \\
\hline
\end{tabular}

In this study, percentage of male, percentage of healthy adults and percentage of highly educated people in the household are considered as the indicators of human capital. The building structure of households is selected as the indicator of physical capital due to its importance on maintaining building safe and family development in the earthquake-affected area. The building structure was assigned a value from 1 to 5 based on its seismic performance. Crop area per capita was considered as the indicator of natural capital. The indicators of financial capital include annual family income and household savings in this study. The diversity of funds and material sources is used to assess social capital in this study. The indicator of funds and material sources was assigned with a value from 1 to 5 based on amount of available ways to get funds and material after disaster. 
To quantitatively assess the livelihood capital or asset, we developed a livelihood capital index (LCI) for rural households' livelihood based on SLA framework. The LCI uses a weighted average approach, to distinguish the impact of different capitals on LCI. We standardized each indicator of the LCI to ensure all indicators on the same scale. The standardization was based on the following equation:

$$
\mathrm{LC}_{j m}=\frac{\mathrm{LC}_{j m}^{\prime}-\operatorname{minLC} C_{j m}^{\prime}}{\operatorname{maxLC}_{j m}^{\prime}-\operatorname{minLC}_{j m}^{\prime}}
$$

where $\mathrm{LC}_{j m}$ represents the normalized value of $m$ indicator in the $j$ capital; $\mathrm{LC}_{j m}^{\prime}$ indicates the initial value of $m$ indicator in the $j$ capital.

Then, we calculated the average value of livelihood capital $j$ using simple average, to avoid the impacts caused by the different number of indicators in livelihood capital components.

$$
\mathrm{LC}_{j}=\sum \mathrm{LC}_{j m} / m
$$

Finally, the LCI of rural household $i$ could be represented by:

$$
\mathrm{LCI}_{i}=\sum_{j=1}^{5} \mathrm{~W}_{j} \mathrm{LC}_{i j} \quad(i \in 1,2, \ldots, 314 ; j \in 1,2, \ldots, 5)
$$

where $\mathrm{LCI}_{i}$ indicates the overall livelihood capital index of rural household $i . \mathrm{W}_{j}$ represents the weight of livelihood capital component $j . \mathrm{LC}_{i j}$ represents the livelihood capital $j$ of rural household $i$. The derived LCI values are between 0 and 1 , where a lower LCI value indicates a lower livelihood capital level.

The weight of each livelihood capital component was determined using Principal Component Analysis (PCA), one of the most widely methods to objectively assign the weights of variables. This method included the following major steps: first, analyzing the principal components of the variables (livelihood capital $j$ ) to obtain the variance of each component and component score coefficient matrix; Then, calculating the coefficient of each variable in the linear combination of different principal components; Third, based on the variance contribution of each component, calculating the coefficient of each variable in the comprehensive score; Finally, obtaining the final weight $\left(\mathrm{W}_{j}\right)$ of each variable by normalizing the coefficient of each variable (Table 2). The analysis could be conducted using SPSS software.

\subsection{Livelihood Strategy}

Livelihood strategy is a collection of livelihood ways and activities for people to pursue livelihood goals, such as income, security and well-being [36,40,41]. Livelihood activity is the concrete manifestation of the rural household's livelihood strategy. However, the classifications of livelihood strategies were not consistent among different studies because of complex livelihood activities of rural households. The most widely used classification is to divide livelihood strategies through household income sources $[23,42]$. If farming is the main livelihood activity, farming income is the main income source of the household and this household could be classified as agricultural household. On the contrary, if non-farming, such as business and occupation work, is the main livelihood activity, this household would be classified as non-agricultural household. Mixed households mean that their income sources include both farming and non-farming incomes. We adopted this classification in our study. Specifically, the classification criteria include: (1) agricultural households: income sources are all from farming income; (2) non-agricultural households: income sources are all from non-farming income; and (3) mixed households: income sources include both farming and non-farming incomes. 


\subsection{Multinomial Logistic Regression}

We applied a multinomial logistic regression (MLR) to determine the key factors affecting asset-based livelihood strategies. The MLR model is more suitable for analyzing the dependent variable with multiple unordered categories. The MLR model can be represented as:

$$
P_{i j}=\frac{\exp \left(\chi_{i}^{\prime} \beta_{j}\right)}{\sum_{i=1}^{n} \exp \left(\chi_{i}^{\prime} \beta_{i}\right)} j=1, \ldots, \mathrm{n}
$$

where $P_{i j}$ indicates the probability of household $i$ choosing livelihood strategy $j$ among $n$ strategies. $\chi_{i}^{\prime}$ is the case-specific regressor of observed livelihood capitals for household $i$. For comparative reference, the $\beta_{i}$ of one strategy category (reference category) was assigned a value of zero and the coefficient was then explained according to the reference category $[43,44]$.

Because the aim of this study focuses mainly on the effects of livelihood assets on livelihood strategies, livelihood asset components and livelihood strategies are treated as independent and dependent variables in the model, respectively. In the analysis, the regression coefficient and odd-ratio values are used to evaluate the influence of livelihood assets on livelihood strategies. Using the data from the agriculture strategy as the reference, the regression coefficient represents the effect of one asset on the probabilities of choosing one livelihood strategy. The odd-ratio value indicates the probability degree of choosing one livelihood strategy in relation to the reference strategy when one asset indicator change.

We used Variance Inflation Factor (VIF) and the tolerance to examine multi-collinearity among independent variables. The results showed that the VIFs were $<1.2$ and the tolerances of all variables were $>0.1$, indicating that multi-collinearity is not a major problem among variables.

\subsection{Questionnaire Investigation and Data Processing}

\subsubsection{Questionnaire Investigation}

A questionnaire-based survey and interviews were conducted for this study based on the Sustainable Livelihoods Framework, a framework that has been widely used for vulnerability assessment $[39,45,46]$. The contents of questionnaire are divided into three parts (Table 3): (1) the personal characteristics of the respondents; (2) the livelihood assets of households; and (3) the livelihood strategy choice of households.

Table 3. Structure of the questionnaire used in this study.

\begin{tabular}{lll}
\hline \multicolumn{1}{c}{ Components } & \multicolumn{1}{c}{ Contents } & \multicolumn{1}{c}{ Indictors } \\
\hline Respondents & $\begin{array}{l}\text { Personal basic } \\
\text { information }\end{array}$ & $\begin{array}{l}\text { socio-demographic characteristics, including gender, age, } \\
\text { ethnic, education, etc. }\end{array}$ \\
\hline $\begin{array}{l}\text { Livelihood } \\
\text { Capitals of } \\
\text { Households }\end{array}$ & Human capital & $\begin{array}{l}\text { the structure of family member, such as the number of } \\
\text { male, healthy adults, highly educated people, etc. }\end{array}$ \\
\cline { 2 - 3 } & Physical capital & building structure of household \\
\cline { 2 - 3 } & Fatural capital & crop area per capita \\
\cline { 2 - 3 } & Social capital & $\begin{array}{l}\text { household savings; annual family income } \\
\text { the ways of funds and material sources to restore and } \\
\text { rebuild for household }\end{array}$ \\
\hline Livelihood Strategies & Livelihood activity types & household income sources \\
\hline
\end{tabular}

To ensure the quality of the response, we selected the household head, who usually know more about the livelihood status than other family members, as the questionnaire respondent in this study. A combined cluster and random sampling method was used to select the respondents. Deducting 
uncompleted questionnaire, we received 311 valid questionnaires completed by the respondents in 23 villages. The effective response rate was up to $97.2 \%$. The sample number is sufficient to meet the needs of a 95\% confidence level and 0.05 sampling error [26].

Table 4 lists the basic characteristics of the questionnaire respondents: $69.75 \%$ male and $30.25 \%$ female respondents because most headers of rural families are male in China. About $63.37 \%$ of the respondents were 30 to 50 years old. Han, Yi and Hani are the main ethnicity, accounting for $92.28 \%$ of the total respondents. In terms of the education level, nearly $80 \%(77.20 \%)$ of the respondents only had attended primary school or secondary school; $22.80 \%$ had a high school or above diploma, indicating relatively low educational level of local rural residents.

Table 4. Characteristics (\%) of the respondents in the studied area.

\begin{tabular}{cccccccc}
\hline \multicolumn{2}{c}{ Gender } & \multicolumn{2}{c}{ Age } & \multicolumn{2}{c}{ Ethnicity } & \multicolumn{2}{c}{ Education } \\
\hline Male & 69.75 & $<30$ & 21.97 & Han & 39.87 & Primary school & 27.69 \\
Female & 30.25 & $30-39$ & 37.26 & Yi & 28.94 & Secondary school & 49.51 \\
& & $40-49$ & 26.11 & Hani & 23.47 & High school & 16.29 \\
& & $50-59$ & 10.19 & Hui & 1.29 & Junior college & 6.19 \\
& & $\geq 60$ & 4.46 & Others & 6.43 & University or above & 0.33 \\
\hline
\end{tabular}

\subsubsection{Data Processing}

The survey data were first input and managed in the Epidata Software System. We then evaluated the connection between livelihood capitals and strategy choices. The procedures of data analysis include: Firstly, we conducted a quantitative estimation of livelihood capitals for local rural households. Next, we analyzed their livelihood strategy choices. The last step was to assess the impacts of livelihood capitals on livelihood strategy choices and identify key impact factors for the selection of livelihood strategies in local households.

\section{Results}

\subsection{Livelihood Capital Level of Local Rural Households}

Figure 2 showed the composite livelihood capital indexes (LCI) of rural households in the study area. The average LCI is 0.32 , indicating a relatively low level of livelihood capitals. The lowest and highest LCI values are 0.12 and 0.61 , respectively. The rural households with LCIs of $<0.20,0.20-0.29$, $0.30-0.39,0.40-0.49$ and $>0.50$ account for $6.37 \%$ (20 households), $39.17 \%$ (123 households), $39.49 \%$ (124 households), $11.46 \%$ (36 households) and 3.51\% (11 households) of the households, respectively. In terms of the five livelihood capital components (Figure 3), the average LCIs of natural capital (0.16) and physical capital (0.25) are lower than those of other capitals (Financial capital 0.37, human capital 0.41 and social capital 0.49 ), indicating uneven distribution of livelihood capital for local households.

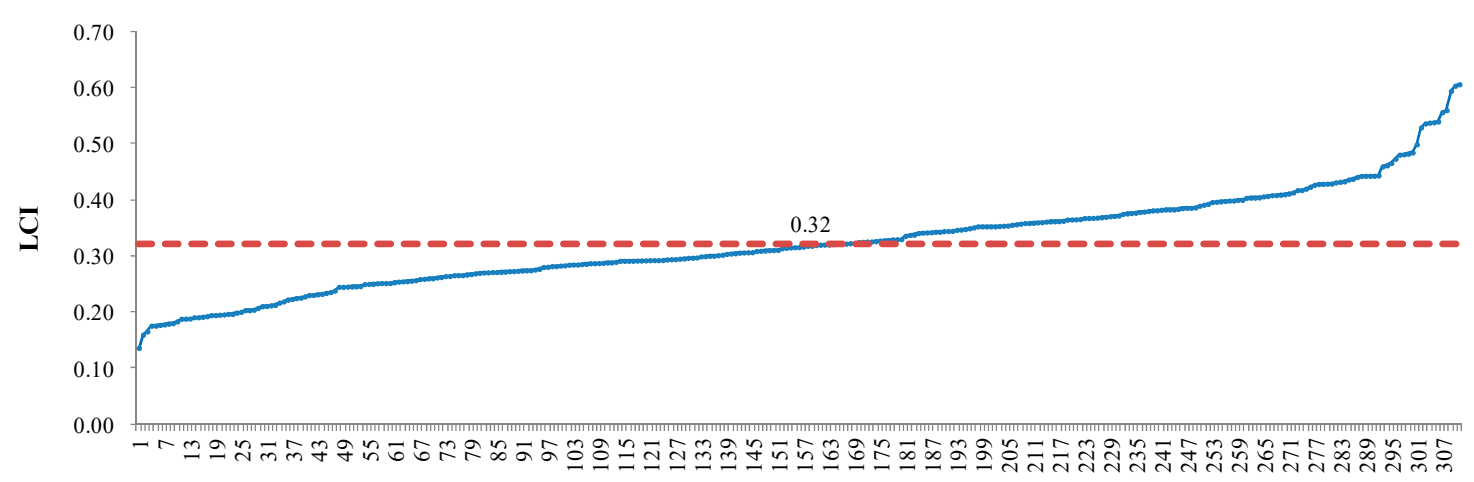

Figure 2. Livelihood capital indexes of rural households in the studied area. 


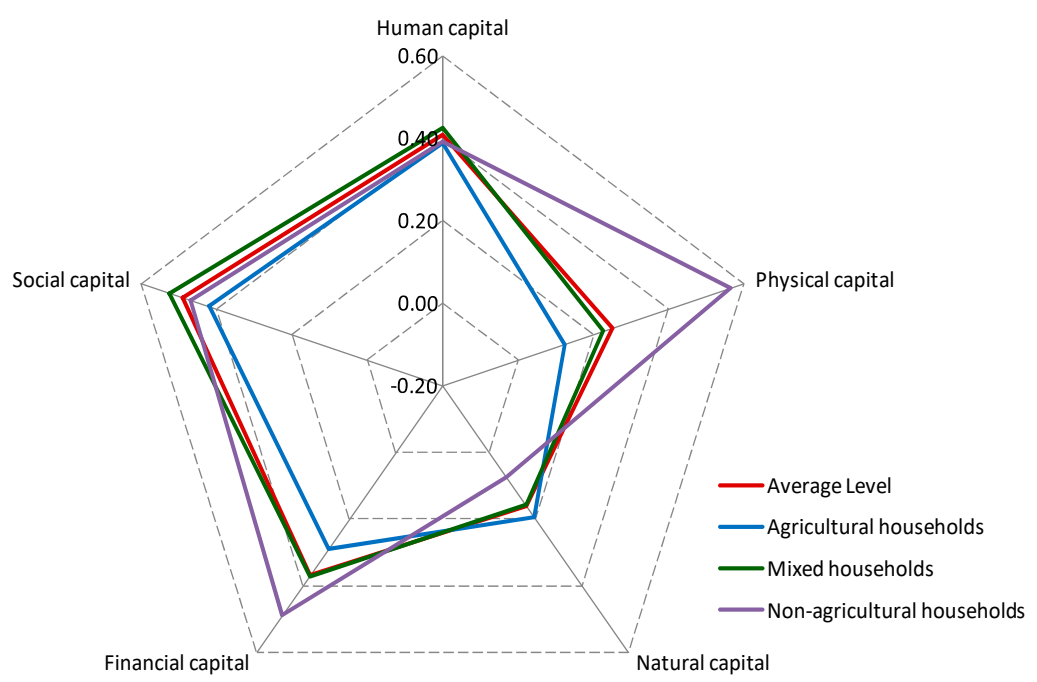

Figure 3. Average livelihood capital indexes of rural households in the studied area.

\subsection{The Characteristics of Livelihood Capitals among Different Livelihood Strategies}

The endowments of households' livelihood capitals determine the choice of livelihood strategies. The allocation of livelihood capitals is important for a household to select a certain livelihood strategy. The differences of livelihood capital endowments exist among different strategies. Table 5 shows the characteristics and differences of livelihood capital endowments among different strategies in the studied area.

Table 5. Livelihood capitals of rural household with different livelihood strategies in Ning'er County.

\begin{tabular}{|c|c|c|c|c|c|}
\hline \multirow{2}{*}{$\begin{array}{l}\text { Types of } \\
\text { Capital }\end{array}$} & \multirow[b]{2}{*}{ Indicators } & \multicolumn{3}{|c|}{ Livelihood Strategies } & \multirow{2}{*}{$\begin{array}{c}\text { ANOVA } \\
\text { Test }\end{array}$} \\
\hline & & $\begin{array}{l}\text { Agricultural } \\
\text { Households }\end{array}$ & $\begin{array}{c}\text { Mixed } \\
\text { Households }\end{array}$ & $\begin{array}{c}\text { Non-Agricultural } \\
\text { Households }\end{array}$ & \\
\hline \multirow{3}{*}{$\begin{array}{l}\text { Human } \\
\text { capital }\end{array}$} & percentage of male $(\%)$ & 50.22 & 49.76 & 46.88 & 0.624 \\
\hline & $\begin{array}{l}\text { percentage of healthy } \\
\text { adults }(\%)\end{array}$ & 67.45 & 75.80 & 69.84 & $4.369 *$ \\
\hline & $\begin{array}{l}\text { percentage of members } \\
\text { with high school degrees } \\
\text { or above }(\%)\end{array}$ & 9.58 & 16.21 & 31.20 & $16.012 * * *$ \\
\hline $\begin{array}{l}\text { Physical } \\
\text { capital }\end{array}$ & building structures (index) & 1.20 & 1.53 & 2.61 & $56.078^{* * *}$ \\
\hline $\begin{array}{c}\text { Natural } \\
\text { capital }\end{array}$ & $\begin{array}{l}\text { crop planting area per } \\
\text { capita (acre) }\end{array}$ & 12.93 & 12.13 & 5.33 & $8.693^{* * *}$ \\
\hline \multirow{2}{*}{$\begin{array}{l}\text { Financial } \\
\text { capital }\end{array}$} & $\begin{array}{l}\text { annual family income } \\
\text { (index) }\end{array}$ & 1.55 & 2.16 & 3.11 & $32.161^{* * *}$ \\
\hline & household savings (index) & 1.33 & 1.56 & 1.83 & $3.194 *$ \\
\hline $\begin{array}{l}\text { Social } \\
\text { capital }\end{array}$ & $\begin{array}{l}\text { the ways of funds and } \\
\text { material sources (number) }\end{array}$ & 1.65 & 2.09 & 1.89 & $6.403 * *$ \\
\hline
\end{tabular}

\subsubsection{Human Capital}

As shown in Table 5, statistically significant difference $(p<0.001)$ exists in the percentage of family members with high education levels among different livelihood strategies. The percentage of members with high school degrees or above $(31.20 \%)$ in non-agricultural households is over three times and nearly two times higher than those in agricultural households $(9.58 \%)$ and mixed households $(16.21 \%)$, 
respectively. The agricultural households have the highest male percentage $(50.22 \%)$ but the difference of the male percentage is not significant among different livelihood strategies. The difference of the percentage of healthy adults is statistically significant $(p<0.05)$ among different strategies. The highest percentage is in the mixed households $(75.80 \%)$, whereas the lowest percentage is in agricultural households $(67.45 \%)$. The difference of the human capital index (HCI) is also statistically significant $(p<0.05)$ among different livelihood strategies (Figure 3). The HCI of mixed households (0.43) is higher than those of non-agricultural (0.39) and agricultural households (0.38).

\subsubsection{Physical Capital}

As shown in Table 5 , there is statistically significant difference $(p<0.001)$ in the structure index of buildings among different strategies. The structure index of buildings is the highest in non-agricultural households (2.61), over two times higher than that in agricultural households (1.20) and one time higher than that in mixed households (1.53). The difference in physical capital index (PCI) is also statistically significant $(p<0.001)$ among different livelihood strategies (Figure 3$)$. The PCI of non-agricultural households (0.57) is higher than those of mixed (0.23) and agricultural households $(0.12)$. This indicates that, relative to the other two livelihood strategies, the buildings of non-agricultural households have better anti-seismic performance to mitigate the earthquake disaster risk.

As illustrated in Figure $4,>80 \%$ of the buildings are assigned to the earth/wood structure (EA/WD buildings). The remaining buildings (about 20\%) are constructed using brick and wood (BR/WD buildings) in the households with agricultural livelihood strategy. In terms of mixed households, the percentage of EA/WD buildings reduced to $59.34 \%$, whereas the percentage of BR/WD buildings increased to $31.87 \%$. In addition, $4.95 \%$ and $3.85 \%$ of the buildings were constructed using brick and concrete (BR/CE buildings) and reinforced concrete (RE/CE buildings), respectively. The percentage of EA/WD buildings significantly reduced to $15.22 \%$ in non-agricultural households. The percentages of $\mathrm{BR} / \mathrm{CE}$ and RE/CE buildings significantly increased to $23.91 \%$ and $26.09 \%$, respectively, in the non-agricultural livelihood strategy. In general, the resilience of RE/CE and BR/CE buildings to earthquakes is much higher than that of BR/WD and EA/WD buildings. Our results suggest that the anti-seismic performance of the buildings in non-agricultural households is better than those of the other two livelihood strategies.

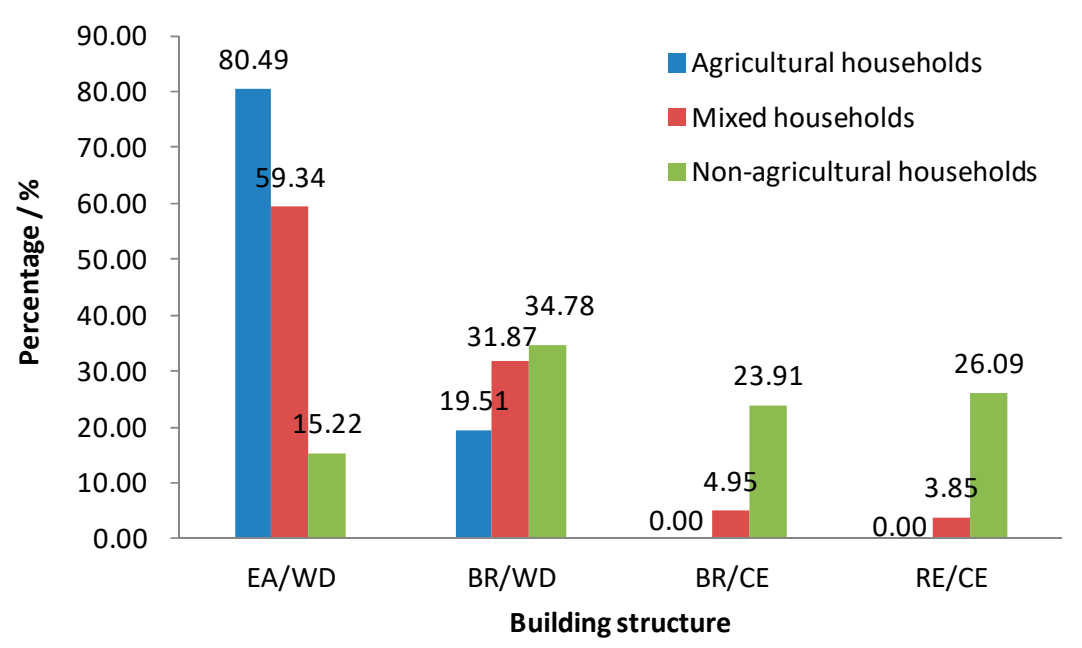

Figure 4. Building structures of three livelihood strategies in studied area.

\subsubsection{Natural Capital}

As shown in Table 5, the difference between crop planting area per capita among different livelihood strategies is significant at the 0.001 level. The residents of agriculture strategy have higher access to crop planting area per capita (12.93 acre) than those of mixed (12.13 acre) and non-agriculture (5.33 acre) strategies. Farming is the principle livelihood choice for local households, especially for 
those with agriculture strategies. Even for the households with non-agriculture strategies, farming also plays an important role in livelihood. Rice, tobacco, tea, vegetables and fruit are the main crops in the area. Looking at the natural capital index (NCI), the difference is also significant at the level of 0.001 among different livelihood strategies (Figure 3). The NCI of agricultural households (0.19) is higher than those of mixed (0.16) and non-agricultural households (0.08).

\subsubsection{Financial Capital}

As expected, non-agriculture strategy has much higher annual family income and household savings than the two other strategies (Figure 5). The annual family incomes of $>50 \%$ of non-agricultural households $(54.35 \%)$ are $>10$ thousand RMB, much higher than the percentages of mixed $(9.89 \%)$ and agricultural households (3.66\%). The percentage of non-agricultural households with annual family income below 5 thousand RMB is $23.91 \%$, lower than those of mixed (56.59\%) and agricultural households $(79.27 \%)$. The trends of household savings are similar among three livelihood strategies. The percentages of the households with no deposit are $>50 \%$ in all three strategies. These results indicate that the overall Financial capital is low for local rural households but the Financial capital of non-agricultural households is better than those of mixed and agricultural households. The ANOVA analysis (Table 5) showed a significant statistical difference $(p<0.001)$ exists in annual family income among different strategies. The difference of household savings is also significant $(p<0.05)$ among different strategies. If we look at the financial capital index (FCI), the difference is significant $(p<0.001)$ among different strategies (Figure 3). The FCI of non-agricultural households (0.49) is significantly higher than those of mixed (0.37) and agricultural households (0.29).
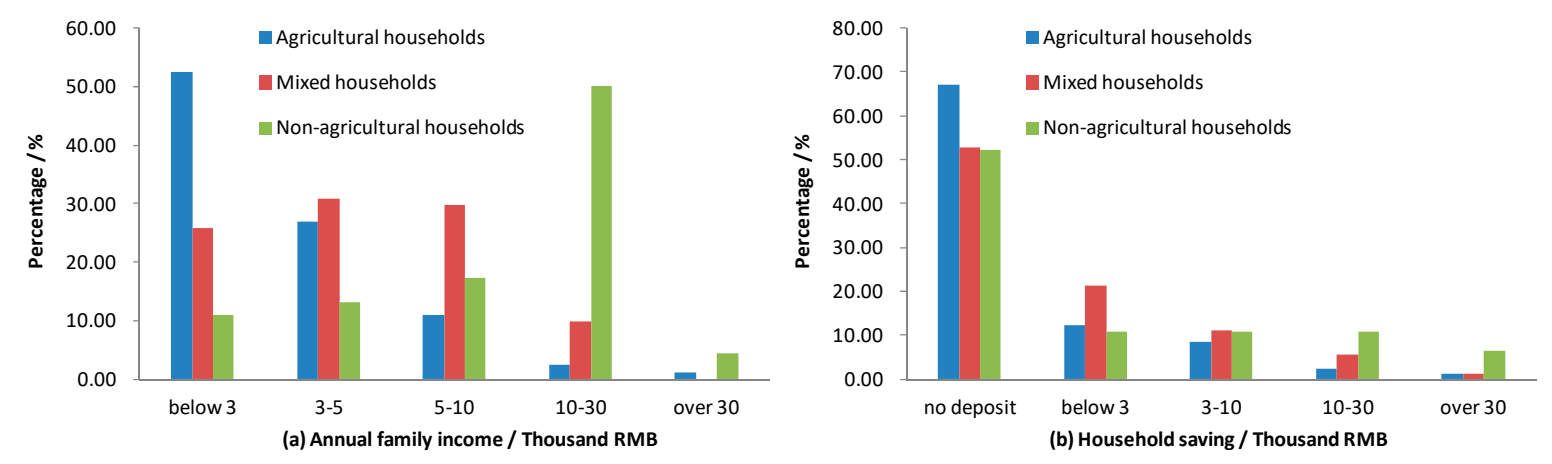

Figure 5. Financial capitals of three livelihood strategies in studied area.

\subsubsection{Social Capital}

As shown in Table 5, the difference is statistically significant $(p<0.01)$ among the number of ways for getting funds and materials in different livelihood strategies. The average number (2.09) of mixed households to get funds is higher than those in non-agricultural (1.89) and agricultural households (1.65). Particularly, about $50 \%$ of agricultural households only have one way to get funds and materials. In contrast, $36.81 \%$ of mixed and $39.13 \%$ of non-agricultural households could get funds and materials from two ways. Furthermore, the proportion of mixed and non-agricultural households with three or four ways to get support are much higher than those of agricultural households (Figure 6). The difference of the social capital index (SCI) is also statistically significant $(p<0.01)$ among different strategies (Figure 3). The SCI of mixed households (0.52) is higher than those of non-agricultural (0.47) and agricultural households (0.42) in the study area. 


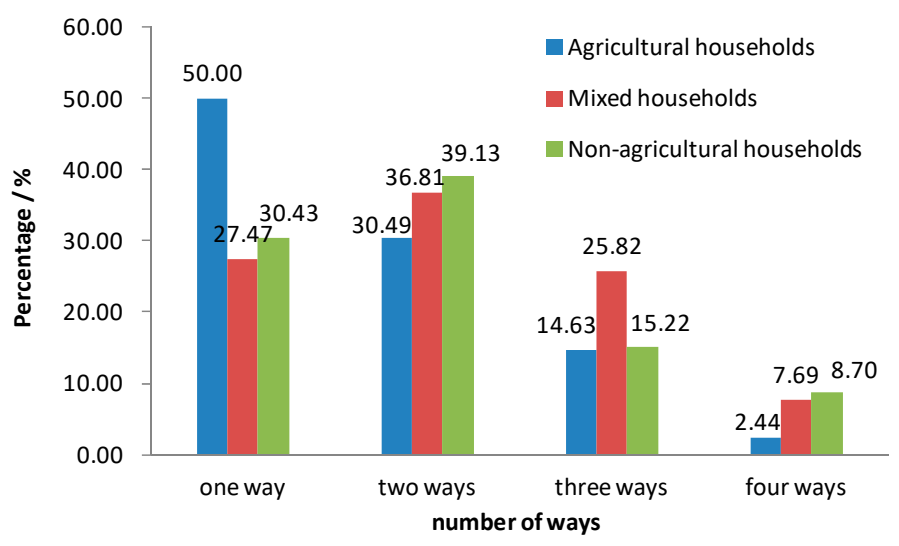

Figure 6. Social capitals of three livelihood strategies in studied area.

\subsection{The Effects of Livelihood Capitals on Livelihood Strategies}

Table 6 lists the results of multinomial logistical regression in determining the correlation between resident capitals and strategies. The regression model was significant with a good fit. The Likelihood Ratio Tests of Model Fitting is significant at the level 0.001. The Cox and Snell R-square value of the model is 0.312 , showing that about $31.2 \%$ of the variance of livelihood strategies (dependent variables) could be explained by livelihood capitals (independent variables). This result suggests that there is a significant effect of livelihood capital on livelihood strategies change of households.

Table 6. Results of Multinomial Logistical Regression.

\begin{tabular}{|c|c|c|c|c|c|c|}
\hline \multirow{2}{*}{$\begin{array}{l}\text { Livelihood Strategies }^{\text {a }} \\
\text { Livelihood Capitals }\end{array}$} & \multicolumn{3}{|c|}{ Mixed } & \multicolumn{3}{|c|}{ Non-Agriculture } \\
\hline & Coefficient & Sig. & $\operatorname{Exp}(B)$ & Coefficient & Sig. & $\operatorname{Exp}(B)$ \\
\hline B & -3.636 & 0.001 & & -3.417 & 0.027 & \\
\hline \multicolumn{7}{|l|}{ Human capitals } \\
\hline Percentage of male & -0.338 & 0.695 & 0.713 & -1.928 & 0.123 & 0.145 \\
\hline Percentage of healthy adults & $2.197^{* * *}$ & 0.001 & 9.002 & 0.518 & 0.591 & 1.678 \\
\hline $\begin{array}{l}\text { Percentage of members with high } \\
\text { education }\end{array}$ & 1.103 & 0.176 & 3.012 & 1.514 & 0.171 & 4.544 \\
\hline \multicolumn{7}{|l|}{ Physical capitals } \\
\hline Building structures & 0.394 * & 0.092 & 1.483 & $1.144^{* * *}$ & 0.000 & 3.139 \\
\hline \multicolumn{7}{|l|}{ Natural capitals } \\
\hline Crop planting area per capita & -0.574 & 0.573 & 0.563 & $-3.596^{* *}$ & 0.039 & 0.027 \\
\hline \multicolumn{7}{|l|}{ Financial capitals } \\
\hline Annual family income & $2.760^{* * *}$ & 0.000 & 15.798 & $4.891^{* * *}$ & 0.000 & 133.045 \\
\hline Household savings & 0.358 & 0.648 & 0.699 & 0.859 & 0.426 & 0.424 \\
\hline \multicolumn{7}{|l|}{ Social capitals } \\
\hline Fund and material sources & $0.675^{* * *}$ & 0.000 & 1.965 & $0.531^{* *}$ & 0.031 & 1.701 \\
\hline
\end{tabular}

Table 6 also shows a positive correlation between the percentage of healthy adults and the possibility of engaging in mixed livelihood strategies. The chance of adopting mixed strategies would increase 9 times as one-unit grow in the percentage of healthy adults. Physical capital is also significant positively correlated with the livelihood strategies choice. The households with RE/CE and BR/CE buildings might be more predisposed to adopt the mixed and non-agriculture strategies than the households with BR/WD and EA/WD buildings. Social capital is also a type of asset that is contribute to the choice of mixed and non-agriculture strategies. The higher social capital, the more local residents tend to select mixed and non-agriculture strategies. The growth of one-unit social capital is likely to increase the selection chance of mixed and non-agriculture strategies 1.97 and 1.70 times, respectively. 
Financial capital has the most important effect on promoting the selection of mixed and non-agriculture strategies. A significant positive correlation exists between annual family income and the possibility of choosing mixed and non-agriculture strategies. The adoption chance of mixed and non-agriculture strategies is likely to grow 15.80 and 133.05 times, respectively, as one-unit increase in annual family income. As expected, natural capital has a significant impact on promoting the adoption of agriculture strategy. One-unit increase in crop planting area per capita might increase the probability of selecting agriculture strategy 37.04 times.

\section{Discussion}

\subsection{Key Influencing Factors on Livelihood Strategy Choice in Earthquake-Affected Area}

An earthquake could severely affect the households' livelihood system, reducing household income and intensifying poverty. The choice of livelihood strategy is of importance for local households to reduce livelihood poverty and recover after the disaster in the earthquake-affected area. It is of great significance to identify the key factors affecting the choice of livelihood strategies for improving the livelihood development and diversifying the livelihood strategies of local residents.

Our findings revealed that financial capital is one of the most important assets in selecting non-farming strategies, such as non-agriculture and mixed livelihood strategies. This result is basically aligned with other relative studies [47]. Financial resources play an essential role in the allocation and conversion among livelihood capitals. However, the accesses of rural residents to financial resources were extremely low in our study area. The annual family income of $79.93 \%$ households is $<10$ thousand RMB. More than $80 \%(82.68 \%)$ of household savings are $<10$ thousand RMB. Moreover, compared to mixed and non-agriculture strategies, the financial capital in the households of agriculture strategy is the lowest.

Similar to other studies [48-50], our study also indicated that the rural households with a high percentage of healthy adults favor the adoption of mixed livelihood strategy. The healthier adults there are, the more likely they have enough manpower to engage new livelihood activities. In addition, our results showed that the education level of family members also plays an important role in the choice of household livelihood strategies. The education level of family members has a positive impact on facilitating the adoption of mixed and non-agriculture strategies. However, the overall education level of local rural area is low, the average percentage of family members with high school degrees or above only accounting for $16.55 \%$ of the total. Generally, more educated family members are more likely to engage in high-returned work or occupation, such as business sector. Due to the low education level, the livelihood activities pursued by local rural households mainly focus on farming, work outside or retail and other business, which require less education but are low-return and low-income. These results are also consistent with other studies for developing countries [51,52].

Social capital is another important factor to promote livelihood strategy diversification. The more the sources of fund and materials, the easier to choose and adopt mixed and non-agriculture strategies. Due to social capitals include all the resources residents could get from social networks, more social resources mean more chance and higher social power to choose the livelihood activities.

Physical and natural capitals also have the significant effects on household livelihood strategies choice. Generally, relative to BR/WD and EA/WD buildings, the resilience of RE/CE and BR/CE buildings to earthquake is much higher but the cost for building RE/CE and BR/CE buildings is also higher than those for BR/WD and EA/WD buildings. Therefore, the households with RE/CE and $\mathrm{BR} / \mathrm{CE}$ buildings might be easier to adopt mixed and non-agriculture strategies than the households with BR/WD and EA/WD buildings, to earn much higher income for supporting family expenditure. Natural capitals facilitate engagement in agriculture strategy, because farming continues to play an important role in the livelihood activities of rural residents and most farmers still rely on natural capitals for their livelihoods [53,54]. 


\subsection{Policy Suggestions on Improving Livelihood Diversification}

Farming is the main livelihood activities of most rural households, which rely mainly on the natural capital, in developing countries [39,55]. However, farming is usually a low-return activity with less possibilities for livelihood recovery after a disaster. Because of the low capability of livelihood capitals accumulation, these rural households could only rely on limited livelihood asset (or capital) to engage in traditional agricultural activities. The products produced might only be self-sufficient and meet their own needs in daily life. This is a traditional livelihood strategy for small-scale farming that they have to adopt under the constraints of their own livelihood assets and external environment. These households engaging in the traditional agricultural livelihood activities would be more vulnerable to natural disaster. Their livelihood characteristics is high risk, low income and strong vulnerability. To increase livelihood outcomes and improve the stability of livelihood, livelihood diversification has become an important way for farmers to reduce poverty and increase home income.

Livelihood diversification is a process in which farmers construct a combination of diversified livelihood activities and social support, in order to meet the needs of maintaining and improving household livelihood level [40]. Livelihood diversification likely increases household resilience and promotes livelihood recovery after a disaster $[56,57]$. Diversifying livelihood has been considered as a useful way to reduce poverty and improve livelihood circumstance in many developing countries. There is a significant positive correlation between livelihood asset endowment and livelihood diversification level of agricultural households [41,58]. Improving the allocation and conversion level among livelihood capitals is an effective method to promote livelihood diversification in the rural area of China.

As analyzed above, financial capital is one of the most essential assets to pursue livelihood strategy. Financial capital could not only be easily converted into other capitals but also be directly used as the achievement of livelihood outcome. Financial capitals mainly include the family income and the accesses to formal and informal credit sources. As expected, non-agriculture and mixed livelihood strategies have higher income and saving levels than agriculture strategies. Choosing higher-return livelihood strategies could result in more family income than lower-return strategies. Therefore, it is necessary to increase financial capitals, including formal and informal loans, especially for agriculture livelihood strategies, to promote rural households in adopting new livelihood strategies, such as businesses and mixed activities. It is recommended that policy makers provide credits and financial assistance to those households who plan to initiate new livelihood activities.

Second, improving the level of human capitals, such as education and technical training, is also important for rural households to develop new livelihood strategies. Due to the requirement of high education level, it is difficult for the households with lower educated members to participate in capital-intensive work or occupation. The low educated residents might only have to engage in the livelihood strategies in which they have work skills and experience. As a result, they are more likely to continue their current lower-return livelihoods. Our results showed that the percentage of members with high school degrees or above in non-agricultural households is over three times higher than that in agricultural households. The education level in agricultural households is the lowest in the three strategies. The choice of livelihood strategies is closely related to family background. Considering human capitals are the key determinant factors in adopting livelihood strategies, it is necessary to made constant efforts to provide higher education and skill training for rural residents. Additionally, vocational planning and guidance is also important for the rural youth. Policymakers should consider developing specific vocational education and skills training policies for the youth, especially those engaging in agricultural strategies, making them have the chance to explore and choose other livelihood strategies.

Third, increasing social capitals is another important policy intervention for rural households to choose new livelihood strategies. Richer social capitals could provide much more social resources and power. For local households, especially agriculture households, participating in local social institutions and groups, such as Rural Cooperatives institutions or Economic Mutual Assistance Group and even becoming a membership of those social groups might be an important and practical way to 
improve their social capitals. People with the memberships of most social groups could get more social information, such as employment opportunities, business information and so forth. The memberships in social groups or organizations could also lead to more social influences and power, which might increase the chances to participate in higher-return and higher-income livelihood strategies. Our results revealed that the households with agriculture strategies have the lowest social capitals. One possible explanation is that the households with agriculture strategies have the lower education and economic level in the study area. Generally, it is necessary for people to have an acceptable level of education and family income to join a social group. At the same time, lower education and economic level will also affect the initiative and enthusiasm of residents to join various social organizations. As a result, in many of cases, the opportunities of the households with agriculture strategies to join these groups were very low, which directly lead to the reduction of their social capitals. Therefore, encouraging agricultural households to actively participate in various local social organizations or groups and formulate one-to-one assistance policies, to improve their livelihood skills and knowledge, is of great practical significance for enhancing their livelihood resilience and enriching their livelihood diversification.

In addition, it is important for the households to improve the anti-seismic performance of house construction and reduce the losses of lives or property caused by earthquakes. However, it is common that most rural house buildings have poor anti-seismic performance in China. In the event of an earthquake, house buildings might be seriously damaged, endangering the livelihood security. For policy makers, it is necessary to provide specific housing construction planning, drawings and technical guidance for rural areas, to enhance the anti-seismic performance of rural house buildings and decrease the livelihood risk.

Finally, for the households in the earthquake-affected area, purchasing family disaster insurance is important to reduce livelihood risk and enhance livelihood flexibility. Disaster insurance is an effective way to decrease the effects of disasters on household livelihoods and promote post-disaster recovery of livelihoods. However, our preliminary investigation found that over half of the households $(53.18 \%)$ have never bought insurance for their family or property. Weak insurance awareness and lack of funds are two main factors affecting residents' purchase of disaster insurance. Thus, it is of great significance to raise disaster insurance awareness by speeding up the publicity and earthquake insurance promotion. On the other hand, decreasing the insurance costs, to encourage rural residents to purchase insurance, are also of great significance for enhancing the recover capacity to earthquake, reducing the impacts of earthquakes on household livelihood. Although the pilot work of earthquake insurance has been launched in Dali, Yunnan in 2015, the effects of its implementation and the degree of acceptance by residents still need further investigation. The efforts to develop the adaptive insurance ways and improve resident's insurance awareness should continue to be enhanced in the future.

Without a doubt, there are many ways for farmers to diversify their livelihoods. In addition to the transformation to non-agricultural livelihood activities, the internal diversification of agriculture livelihood could also be implemented in the areas with good endowment of agricultural resources. Policymakers should guide the farmers to improve their livelihood strategies and realize the livelihood diversification transformation, according to the regional geographical environment and the comparative advantages of farmers' own livelihood assets.

\section{Conclusions}

The study analyzed the characteristics of livelihood assets (or capitals) among different livelihood strategies and estimated the effects of livelihood assets on the selection of livelihood strategies in Ning'er earthquake-stricken area. The results showed statistically significant differences in the livelihood assets among three livelihood strategies in local rural households. The livelihood capital level of the agricultural households is generally the lowest in the three livelihood strategies. The endowment of household livelihood assets has a significant impact on the choice of livelihood strategies. Financial capitals, social capitals and physical capitals have significant positive correlations with non-agricultural and mixed strategies choices. As expected, natural capital have a positive influence on the choice of 
agriculture strategy. In terms of human capital, percentage of healthy adults and members with high education has a significant positive effect on the selection of non-agricultural and mixed strategies.

High financial capital could enable households to engage much higher-return or capital-intensive livelihood activities. It is of importance to increase financial capitals, including formal and informal loans, to promote households to initiate new livelihood strategies and develop livelihood diversification. Rich human capitals could provide more opportunities for local residents to develop new livelihood activities. Youth vocational education and skills training, especially for the youth engaging in agriculture strategy, should be given priority in future policy making. Higher social capitals could provide higher social resources and influence, which might also increase the opportunity to select a higher-returns and higher income livelihood strategy. Encouraging rural households to actively participate in local social organizations or groups and formulate one-to-one assistance policies, is also of great practical significance for enhancing their livelihood resilience and promoting their livelihood diversification. It is also necessary for policy maker to provide housing construction planning and technical guidance, to enhance the anti-seismic performance of rural house buildings and decrease their livelihood risk. Additionally, increasing disaster insurance awareness, decreasing the insurance costs, encouraging rural households to purchase insurance, is also important to reduce livelihood risk and enhance livelihood flexibility in the earthquake-prone area. Finally, although the ways for farmers to diversify their livelihood are various, improving the livelihood strategies according to the regional geographical environment and the comparative advantages of farmers own livelihood assets or capitals, is the realistic basis for realizing the transformation of farmers' livelihood diversification.

There are some limitations of this study. The most notable limitation is the evaluation indicators were designed for earthquake-affected area and chose based on the available data in local rural communities. As a result, the evaluation indicators system might not be directly applied to other areas. More detailed work is necessary to include refined indicators, the classifications of livelihood strategy, the livelihood asset dynamic changes as the improvement and update of survey data in the future. For example, in the future work, we would try to improve the livelihood assessment indicator system of rural households based on the sustainable livelihood framework, integrating the concepts of vulnerability assessment. For each type of livelihood capitals, not only the quantity of capitals (such as area, number, output and so on) but also the quality of capitals (such as performance, level, degree and so on) could be considered. The sources of family income and the specific types of livelihood activities rural residents engage in, might be taken into account in the classification of household's livelihood strategies.

Author Contributions: Conceptualization, B.W. and G.S.; methodology, B.W.; formal analysis, B.W.; investigation, G.S. and B.W.; data curation, Y.M.; writing-original draft preparation, B.W.; writing-review and editing, Y.L.

Funding: This research was funded by National Natural Science Foundation of China, grant number 41601567; National Natural Science Foundation of China, grant number 4180071278; and National Natural Science Foundation of China, grant number 40971274.

Acknowledgments: We would like to express our thanks for the support from National Natural Science Foundation of China (41601567; 4180071278; 40971274). Special thanks to the reviewers for their pertinent suggestions.

Conflicts of Interest: The authors declare no conflict of interest.

\section{References}

1. Carter, M.R.; Little, P.D.; Mogues, T.; Negatu, W. Poverty traps and natural disasters in Ethiopia and Honduras. World Dev. 2007, 35, 835-856. [CrossRef]

2. Cutchin, M.P.; Martin, K.R.; Owen, S.V.; Goodwin, J.S. Concern about petrochemical health risk before and after a refinery explosion. Risk Anal. 2008, 28, 589-601. [CrossRef] [PubMed]

3. Su, G.W.; Ma, Z.J.; Wang, R.J.; Wang, Y.; Dai, B.Y.; Zhang, S.W.; Mi, Q.W.; Zhang, S.S. General features and their disaster-reduction education implications of the earthquake disaster cognition and responses of the social public in Ms8.0 Wenchuan earthquake-hit area: A case study from Deyang prefecture-level region, Sichuan province. Seismol. Geol. 2008, 30, 877-894. 
4. Dercon, S. Wealth, risk and activity choice: Cattle in Western Tanzania. J. Dev. Econ. 1998, 55, 1-42. [CrossRef]

5. Carter, M.R.; Barrett, C.B. The economics of poverty traps and persistent poverty: An asset-based approach. J. Dev. Stud. 2006, 42, 178-199. [CrossRef]

6. Barrett, C.B. Rural poverty dynamics: Development policy implications. Agric. Econ. 2005, 32, 45-60. [CrossRef]

7. Forster, J.; Lake, I.R.; Watkinson, A.R.; Gill, J.A. Marine dependent livelihoods and resilience to environmental change: A case study of Anguilla. Mar. Policy 2014, 45, 204-212. [CrossRef]

8. Fang, Y.P.; Zhu, F.B.; Qiu, X.P.; Zhao, S. Effects of natural disasters on livelihood resilience of rural residents in Sichuan. Habitat Int. 2018, 76, 19-28. [CrossRef]

9. Scoones, I. Livelihoods perspectives and rural development. J. Peasant Study 2009, 36, 171-196. [CrossRef]

10. Thulstrup, A.W. Livelihood resilience and adaptive capacity: Tracing changes in household access to capital in Central Vietnam. World Dev. 2015, 74, 352-362. [CrossRef]

11. Marschke, M.J.; Berkes, F. Exploring strategies that build livelihood resilience: A case from Cambodia. Ecol. Soc. 2006, 11, 42. [CrossRef]

12. Merritt, W.S.; Patch, B.; Reddy, V.R.; Syme, G.J. Modeling livelihoods and household resilience to droughts using Bayesian networks. Environ. Dev. Sustain. 2016, 18, 315-346. [CrossRef]

13. Ademola, A.; Adebukola, D.; Adeola, C.S.; Cajetan, A. Effects of natural disasters on social and economic well-being: A study in Nigeria. Int. J. Disaster Risk Reduct. 2016, 17, 1-12.

14. Daramola, A.Y.; Oni, O.T.; Ogundele, O.; Adesanya, A. Adaptive capacity and coping response strategies to natural disasters: A study in Nigeria. Int. J. Disaster Risk Reduct. 2016, 15, 132-147. [CrossRef]

15. Li, X.Y.; Dong, Q.; Rao, X.L.; Zhao, L.X. Method for vulnerability analysis of rural household and its localization application. Chin. Rural Econ. 2007, 4, 32-39.

16. Yan, J.Z.; Yu, O.; Wu, Y.Y.; Zhang, Y.L. Livelihood vulnerability assessment of farmers and nomads in Eastern Ecotone of Tibetan Plateau, China. Sci. Geogr. Sin. 2011, 31, 858-867.

17. He, R.W.; Liu, S.Q.; Liu, Y.W.; Li, L.; Liang, L.; Li, T.T. Evaluation and spatial distribution of farmer's livelihood capital in representative mountain areas: A case study of Liangshan Yi Autonomous Prefecture of Sichuan. China Mt. Res. 2014, 32, 641-651.

18. Liu, J.; Fu, B.; Wang, Y.K.; Xu, P. Comparative analysis of farmer households' livelihood in the typical mountainous regions of Western China: A case study of Baoxing County, Sichuan Province. J. China Agric. Univ. 2016, 21, 144-154.

19. Hu, H.; Si, Y.F.; Wang, L.J. The impact of industrial poverty alleviation strategies on the livelihoods and household incomes of the rural poor: An empirical analysis from Shaanxi Province. Chin. Rural Econ. 2018, 1, 78-89.

20. Quan, L.; Chen, Y.P. Analysis on livelihood assets mobility and its influencing factors of rural households. J. Huazhong Agric. Univ. (Soc. Sci. Ed.) 2018, 2, 127-136.

21. Su, F.; Pu, X.D.; Xu, Z.M.; Wang, L. Analysis about the Relationship Between Livelihood Capital and Livelihood Strategies: Take Ganzhou in Zhangye City as a Example. China Popul. Resour. Environ. 2009, 19, 119-125.

22. He, Z.L.; Mi, X.; Yu, K.R.; Zeng, M. The relationship between peasants' livelihood capital and tourism livelihood strategy-A case study conducted in area A of Northwest China. J. Guangxi Univ. Natl. 2017, 39, 61-68.

23. Liu, Z.; Li, J.; Dong, G.; He, R. Farmers' household strategies and their transitional dynamics: A study from the data of 451 farmers in Ningxia Hui Autonomous Region. World Reg. Stud. 2017, 26, 61-72.

24. Luo, X.F.; Jiang, S.Y.; Leng, J.L. Analysis of peasant household's disaster vulnerability in Jianghan Plain. J. Huazhong Agric. Univ. (Soc. Sci. Ed.) 2012, 1, 17-20.

25. Han, Z.Q.; Ba, Z.L.; Xin, R.P.; Zhong, P. Rural households recovery after disasters: From the sustainable livelihoods perspective. China Popul. Resour. Environ. 2016, 26, 158-167.

26. Wei, B.Y.; Su, G.W.; Qi, W.H.; Sun, L. The Livelihood Vulnerability of Rural Households in Earthquake-Stricken Areas-A Case Study of Ning'er, Yunnan Province. Sustainability 2016, 8, 566. [CrossRef]

27. Qiu, X.P.; Yang, X.T.; Fang, Y.P.; Xua, Y.; Zhu, F.B. Impacts of snow disaster on rural livelihoods in southern Tibet-Qinghai Plateau. Int. J. Disaster Risk Reduct. 2018, 31, 143-152. [CrossRef] 
28. Wang, R.J.; Su, G.W.; Zhang, S.W.; Gong, Q.; Wu, Q.; Chen, Z.S. A preliminary study on the characteristics of cognition on and response to earthquake disaster of the middle school students in Puer area, Yunnan province, China: A case study on the 2007 Ning'er earthquake with Ms6.4. J. Catastrophol. 2009, 24, 133-138.

29. Qi, W.H.; Wu, Q.; Su, G.W.; Gong, Q.; Ma, F.Y.; Wang, R.J.; Chen, Z.S. Research in recovery and reconstruction mode on rural housing at Ning'er Ms6.4 earthquake disaster in 2007: A case study of Mingzheng village in Ning'er county. J. Seismol. Res. 2012, 35, 268-275.

30. Wei, B.Y.; Su, G.W.; Wu, Q.; Qi, W.H.; Zhang, W.J. Features of awareness and response of rural households and their inter-household differences to earthquake disasters: A case study of the disaster area of Ms 6.4 Ning'er, Yunnan earthquake in 2007. J. Nat. Disasters 2012, 21, 116-124.

31. Wei, B.Y.; Su, G.W.; Liu, F.G. Public response to earthquake disaster: A case study in Yushu Tibetan Autonomous Prefecture. Nat. Hazards 2013, 69, 441-458. [CrossRef]

32. Jin, Y.F.; Wei, B.Y.; Su, G.W.; Zhang, H.F.; Sun, L.; Wu, Y. A pilot survey and preliminary analysis of earthquake disaster cognitive level among the government officials in Yushu Qinghai. J. Catastrophol. 2015, 30, 229-234.

33. Sun, L.; Su, G.W.; Tian, Q.; Qi, W.H.; Liu, F.G.; Qi, M.; Li, R.Y. Religious belief and Tibetans' response to earthquake disaster: A case study of the 2010 Ms 7.1 Yushu earthquake, Qinghai Province, China. Nat. Hazards 2019, 99, 141-159. [CrossRef]

34. Zhang, Y.; Xu, L.S.; Chen, Y.T.; Feng, W.P.; Du, H.L. Source process of Ms 6.4 earthquake in Ning'er, Yunnan in 2007. Sci. China Ser. D Earth Sci. 2009, 52, 180-188. [CrossRef]

35. Siegel, P.B. Using an Asset-Based Approach to Identify Drivers of Sustainable Rural Growth and Poverty Reduction in Central America: A Conceptual Framework. World Bank Policy Research Working Paper. Available online: http://www-wds.worldbank.org/servlet/WDSContentServer/WDSP/IB/2005/01/19/ 000160016_20050119144447/Rendered/PDF/WPS3475.pdf (accessed on 25 May 2013).

36. Chambers, R.; Conway, G. Sustainable Rural Livelihoods: Practical Concepts for the 21st Century; IDS Discussion Paper 296; Institute of Development Studies: Brighton, UK, 1992.

37. Neiland, A.E. Fisheries Development, Poverty Alleviation and Small-Scale Fisheries: A Review of Policy and Performance in Developing Countries Since 1950. In Poverty and Small-Scale Fisheries in West Africa; Neiland, A.E., Béné, C., Eds.; Springer: Dordrecht, The Netherlands, 2004.

38. Stirrat, R.L. Yet another magic bullet: The case of social capital. Aquat. Resour. Cult. Dev. 2004, 1, $25-33$.

39. DFID. Better Livelihoods for Poor People: The Role of Agriculture; Department for International Development: London, UK, 2002.

40. Ellis, F. Household strategies and rural livelihood diversification. J. Dev. Stud. 1998, 35, 1-38. [CrossRef]

41. Van den Berg, M. Household income strategies and natural disasters: Dynamic livelihoods in rural Nicaragua. Ecol. Econ. 2010, 69, 592-602. [CrossRef]

42. Yan, J.; Wu, Y.; Zhang, Y.; Zhou, S. Livelihood diversification of farmers and nomads of eastern transect in Tibetan Plateau. J. Geogr. Sci. 2010, 20, 757-770. [CrossRef]

43. Parrot, L.; Dongmo, C.; Ndoumbé, M.; Poubom, C. Horticulture, livelihoods, and urban transition in Africa: Evidence from South-West Cameroon. Agric. Econ. 2008, 39, 245-256. [CrossRef]

44. Cameron, A.; Trivedi, P.K. Microeconometrics Using Stata; Stata Press: College Station, TX, USA, 2009.

45. Ellis, F. Rural Livelihoods and Diversity in Developing Countries; Oxford University Press: Oxford, UK, 2000.

46. Speranza, C.I.; Kiteme, B.; Wiesmann, U. Droughts and famines: The underlying factors and the causal links among agro-pastoral households in semi-arid Makueni district, Kenya. Glob. Environ. Chang. 2008, 18, 220-233. [CrossRef]

47. Paudel Khatiwada, S.; Deng, W.; Paudel, B.; Khatiwada, J.R.; Zhang, J.; Su, Y. Household livelihood strategies and implication for poverty reduction in rural areas of Central Nepal. Sustainability 2017, 9, 612. [CrossRef]

48. Khalyani, J.H.; Namiranian, M.; Vaezin, S.H.; Feghhi, J. Development and evaluation of local communities incentive programs for improving the traditional forest management: A case study of Northern Zagros forests, Iran. J. For. Res. 2014, 25, 205-210. [CrossRef]

49. Peng, W.; Zheng, H.; Robinson, B.E.; Li, C.; Wang, F. Household livelihood strategy choices, impact factors, and environmental consequences in Miyun Reservoir Watershed, China. Sustainability 2017, 9, 175. [CrossRef]

50. Dehghani Pour, M.; Motiee, N.; Barati, A.A.; Taheri, F.; Azadi, H.; Gebrehiwot, K.; Lebailly, P.; Van Passel, S.; Witlox, F. Impacts of the Hara Biosphere Reserve on livelihood and welfare in Persian Gulf. Ecol. Econ. 2017, 141, 76-86. [CrossRef] 
51. Mamo, G.; Sjaastad, E.; Vedeld, P. Economic dependence on forest resources: A case from Dendi District, Ethiopia. For. Policy Econ. 2007, 9, 916-927. [CrossRef]

52. Jha, S. Household-specific variables and forest dependency in an Indian hotspot of biodiversity: Challenges for sustainable livelihoods. Environ. Dev. Sustainability 2009, 11, 1215. [CrossRef]

53. Diniz, F.; Hoogstra-Klein, M.; Kok, K.; Arts, B. Livelihood strategies in settlement projects in the Brazilian Amazon: Determining drivers and factors within the Agrarian Reform Program. J. Rural Stud. 2013, 32, 196-207. [CrossRef]

54. Naidu, S.C. Legal exclusions, private wealth and livelihoods: An analysis of work time allocation in protected areas. Ecol. Econ. 2013, 89, 82-91. [CrossRef]

55. Bryan, E.; Ringler, C.; Okoba, B.; Roncoli, C.; Silvestri, S.; Herrero, M. Adapting agriculture to climate change in Kenya: Household strategies and determinants. J. Environ. Manag. 2013, 114, 26-35. [CrossRef]

56. Huber, F.; Yang, Y.; Weckerle, C.; Seeland, K. Diversification of livelihoods in a society in transition: A case study of Tibetan communities in Southwest China. Soc. Nat. Resour. 2014, 27, 706-723. [CrossRef]

57. Hua, X.B.; Yan, J.Z.; Zhang, Y.L. Evaluating the role of livelihood assets in suitable livelihood strategies: Protocol for anti-poverty policy in the Eastern Tibetan Plateau, China. Ecol. Indic. 2017, 78, 62-74. [CrossRef]

58. Li, J.; Li, Y.L.; Tai, X.J.; Li, C. Livelihood analysis of rural households in the poverty-stricken mountainous areas of Western China based on the framework of sustainable livelihood analysis. China Rural Surv. 2009, 5, $29-38$.

(C) 2019 by the authors. Licensee MDPI, Basel, Switzerland. This article is an open access article distributed under the terms and conditions of the Creative Commons Attribution (CC BY) license (http://creativecommons.org/licenses/by/4.0/). 